EDITORIAL

Rev Chil Salud Pública 2014; Vol 18 (2): 125-126

\section{UN MUNDO EN EL MUNDO}

\section{A WORLD WITHIN THE WORLD}

Miguel Kottow

Escuela de Salud Pública Facultad de Medicina Universidad de Chile mkottow@gmail.com
Agua abundante, en forma de copos, gotas, chorros, torrentes, caídas, lagunas. Agua de excelencia, dando origen a cervezas locales de primera; agua traicionera congelando cañerías, solidificada en tazas de baño hasta reventarlas, tanto que algunas dueñas de casa previsoras enriquecen el depósito con descongelante para mantener el artefacto operativo. Coyhaique hídrico, hidro-Coyhaique, defendiendo sus aguas de la represión energética, del enclaustramiento: "Patagonia sin represas" en armas contra HidroAysén.

La salud pública y la atención médica son de tal modo organizadas y eficaces, que apenas hay medicina privada, ninguna clínica, todos los médicos, la atención de urgencia y una altamente resolutiva medicina asistencial pertenecen al área pública; el 75 por ciento de la fuerza laboral es empleada por el Estado. La red de atención rural distribuye 30 postas en un territorio que abarca el 14,2 por ciento del país. Todos hacen lo que pueden, y más. Como todo espacio insular con vida propia, los coyhaiquinos, nativos, pasajeros o transeúntes, están ávidos de puentes, de conexión; no quieren programas asistenciales, buscan cooperación, interacción. El aislamiento y la accidentada geohidrografía han requerido un alto poder de gestión a todo nivel, desde salud a transportes, desde hospitales hasta educación...

Y si el párrafo termina en educación suspensiva, es porque a nivel de educación superior es donde Coyhaique busca situarse y donde la Escuela de Salud Pública viene de establecer un memorándum de entendimiento, confirmando la buena disposición y el plan de iniciar ahora, no en un nebuloso futuro, un Diplomado en Salud Pública cuyos módulos se diseñan desde la academia, pero hacia las necesidades locales, reemplazando la cátedra por la interacción reflexiva, participando en la siembra de una vida académica dinámica, de una institucionalidad universitaria que acoge, enseña y comparte, en un proceso cuya metáfora, ya utilizada en otros contextos, no solo baje de internet sino que también suba desde el mundo de Aysén al Chile Mundo.

Líneas estas escritas desde otra ciudad, donde lo primero que se escucha es el escaso compromiso con la medicina pública, que compite en desventaja con las instalaciones privadas, los profesionales de la salud que migran 
a las clínicas, a la metrópoli, a la especialización exquisita. Brutal contraste. Rp.: una visita a Coyhaique.

Keynesiana, dice un compañero de ruta, pero quizás si un enfoque más preciso mostrara a Coyhaique como un ejemplo de políticas de Estado, influidas, sí, por gobiernos de turno, pero sin perder el norte y con capacidad de estabilizar la brújula cuando los vientos políticos son más alisios.

Los patagónicos dejan huellas grandes. Leámoslas. Participemos en la impronta. 